\title{
Soukromé doučování a vzdělávací politiky v Evropě
}

\author{
Vít Št’astný
}

Univerzita Karlova, Pedagogická fakulta, Ústav výzkumu a rozvoje vzdělávání

Redakci zasláno 14. 3. 2014 / upravená verze obdržena 10. 6. 2014 /

k uveřejnění přijato 18. 6. 2014

\begin{abstract}
Abstrakt: Cílem studie je identifikovat a zařadit vybrané evropské země do jednotlivých typů Brayovy typologie vzdělávacích politik ve vztahu k soukromému doučování $(1999,2009)$ a s využitím dostupných empirických studií představit zavedená opatření a jejich dopady. V první části příspěvku autor definuje soukromé doučování a jeho možné implikace pro formální vzdělávací systém a jeho spravedlnost. Ve druhé části autor představuje Brayovu typologii vzdělávacích politik ve vztahu k soukromému doučování a její vývoj v čase. Jednotlivé typy vzdělávacích politik jsou uvedeny na konkrétních př́íkladech evropských zemí. Ve třetí části je pak diskutována aktuální situace v České republice. V Evropě je možné identifikovat nejen země podporující soukromé doučování (Francie), ale i země tento fenomén do určité míry regulující (Litva, Německo, Slovensko), nebo i takové, které se k soukromému doučování staví nevšímavě (Chorvatsko). Uvedené příklady demonstrují různorodost podob stínového vzdělávacího systému v různých kontextech a dosavadní reakce tvůrců vzdělávací politiky na něj. Nezájem o tento fenomén v České republice ostře kontrastuje s doporučeními světových odborníků na tuto problematiku. Zároveň v našem kontextu chybí relevantní výzkumná data, o která by bylo možné opřít politické rozhodování.
\end{abstract}

Klíčová slova: soukromé doučování, stínové vzdělávání, spravedlnost ve vzdělávání, Evropská unie, regulace, legislativa

„Stresovaní rodiče hledají soukromé doučování“1 „, „Vzestup soukromého do-

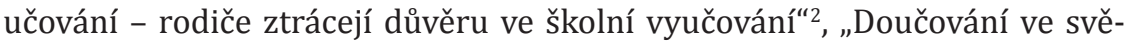
tě prosperuje tam, kde škola selhává“ ${ }^{3}$ či „Bez doučování ani ránu“4 . To jsou jen některé ze stovek novinových a časopisových titulků z posledních let, které narážejí na problematiku soukromého doučování jako tzv. stínového vzdělávání a zároveň implikují i některé kontroverzní otázky spojené s do-

\footnotetext{
Parents stressés cherchent soutien scolaire (Belot, 2011).

Education: Private tutoring is on the rise (Loveys, 2011).

Dans le monde, le soutien scolaire prospère là où l'école faillit (Franghi, 2011).

4 Bez korepetycji ani rusz (Koleticiek, 2005).
}

DOI: $10.5817 /$ PedOr2014-3-353 
pady placeného doučování na spravedlnost ve vzdělávání. V tomto článku některé z nich na konkrétních příkladech nastíníme. První část stati uvádí do problematiky soukromého doučování, vysvětluje, proč je důležité se jí zabývat, a také v teoretické rovině představuje možné postoje vlád a jejich vzdělávací politiky ve vztahu $\mathrm{k}$ tomuto fenoménu. Jako konceptuální rámec druhé části je $\mathrm{v}$ článku využita Brayova typologie přístupů vlád $\mathrm{k}$ tomuto fenoménu, kterou nastínil ve svých publikacích $(1999,2003)$.

$\mathrm{V}$ př́spěvku si autor klade za cíl identifikovat a zařadit vybrané evropské země do jednotlivých typů Brayovy typologie v Evropě, a to na základě analýzy dokumentů, zejména platné legislativy, směrnic a nařízení, doporučení, vládních i nevládních dokumentů, odborných zpráv a také studia odborných publikací a dalších zdrojů. Tato typologie byla v minulosti uváděna zejména v souvislosti s mimoevropskými státy, ${ }^{5}$ je proto aktuální a přínosné ji aplikovat v podmínkách sjednocující se Evropy. Typologie je dále doplněna o další odborné zdroje a obohacena o závěry z empirických nálezů, čímž jsou uvedené legislativní texty uvedeny do kontextu s jejich reálnými dopady. V závěru jsou navrhnuty možné cesty, kterými by se mohla ubírat česká vzdělávací politika v této oblasti. Sekundárně si tato přehledová studie klade za cíl iniciovat diskuzi nad tématem, které u nás prozatím stojí na okraji zájmu výzkumníků.

\section{Soukromé doučování jako „stínový vzdělávací systém“}

V tomto příspěvku je soukromé doučování chápáno v souladu s definicí Danga a Rogerse $(2008$, s. 162) jako „... placené doučování poskytované žákům nad rámec výuky ve škole ve školních předmětech". ${ }^{6} \mathrm{~V}$ souvislosti se soukromým doučováním bývá často zmiňován i pojem stínové vzdělávání. $\mathrm{V}$ češtině může mít přívlastek stínový negativní konotace (např. stínová ekonomika), nicméně tato metafora má své opodstatnění. Soukromé doučování je specifickým druhem vzdělávání úzce provázaným se školou

\footnotetext{
Např. Dang a Rogers (2008) se pokusili klasifikovat 20 zemí, z nich však pouze 4 evropské.

„... fee based tutoring that provides supplementary instruction to children in academic subjects that they study in the mainstream education system" (překlad autora). Brehm a Silova (2014) identifikovali na základě studia literatury čtyři různé konceptualizace fenoménu: (a) jako kulturní fenomén odrážející vnímanou hodnotu snahy a úsilí pro vzdělávací úspěch, (b) strategii „nadstavby“ (enrichment) jako přípravy na high-stakes zkoušky, (c) strategii „nápravy“ (remedial) pomáhající žákům zvládnout požadavky kladené na ně školou, a konečně (d) mechanismus pro ekonomické přežití učitelů s nízkými platy.
} 
a školním kurikulem. Právě ona provázanost vede k jisté „imitaci“ formálního školství, což některé autory přimělo k použití metafory „stínu“. Např́íklad Mark Bray pojmenoval svoji první přehledovou monografii týkající se soukromého doučování The shadow education system (1999). Také vysvětluje a zdůvodňuje, proč se metafora stínu jeví jako velmi výstižná: (a) soukromé doučování existuje pouze díky existenci formální školní výuky (stejně jako stín díky předmětu, který jej vrhá); (b) změní-li se podoba formálního vzdělávání, změní se i charakteristika soukromého doučování; (c) ve většině společností je mnohem větší pozornost věnována formálnímu vzdělávacímu systému, nikoliv stínu (doučování); a konečně (d) rysy a vlastnosti systému soukromého doučování jsou mnohem méně ostré a jasné než u formálního vzdělávání (s. 17).

Fenomén soukromého doučování tedy není možné vnímat izolovaně, nýbrž v úzké spojitosti $\mathrm{s}$ formálním vzdělávacím systémem. V současném akademickém diskurzu se často upozorňuje $\mathrm{v}$ celosvětovém měřítku na stále větší míru pronikání soukromého sektoru do oblasti veřejného vzdělávání, což souvisí neo-liberalismem a ideologií nového veřejného managementu (např. Burch, 2009; Ball \& Youdell, 2008). Ve své výzkumné zprávě nazvané př́iznačně Skrytá privatizace ve veřejném vzdělávání autoři (Ball \& Youdell, 2008) na základě studia pramenů z různých zemí identifikovali dva druhy této privatizace, tzv. endogenní a exogenní. $V$ prvním př́ípadě se jedná o privatizaci ve veřejném školství (privatisation in public education), jejímž principem je importování některých praktik či principů ze soukromého sektoru do fungování veřejných škol. To se projevuje tendencemi požadovat po veřejném sektoru, aby se choval tržněji, zdůrazňuje se efektivita, boj o žáka, soutěž mezi školami má vést ke zvyšování jejich efektivity či standardů v celém vzdělávacím systému. Druhý případ označovaný jako exogenní privatizace znamená privatizaci veřejného školství (privatisation of public education) zahrnující outsourcing některých služeb a funkcí a aspektů veřejného vzdělávání na soukromé poskytovatele. Oba druhy privatizace nemusejí být na první pohled zřejmé a veřejnosti známé. Jako př́klady druhé formy privatizace uvádějí autoři rostoucí množství externích konzultantů, partnerství veřejného a soukromého sektoru či komercializaci a nabídku produktů některých nadnárodních společností přímo ve školách výměnou za sponzorské dary. Zanedbatelné nejsou ani další prakticky povinné náklady rodičů spojené se vzděláváním ve veřejných školách, jako je nákup učebnic či dalších pomůcek nebo poplatků za využívání sportovních zařízení během hodin 
tělesné výchovy. $V$ českém prostředí lze tyto privatizační tendence rovněž pozorovat například $\mathrm{v}$ podobě outsourcingu tvorby a vyhodnocení přijímacích zkoušek (na víceletá gymnázia či vysoké školy) soukromým institucím. Po vydání této zprávy se ozvaly kritické hlasy z řad výzkumníků zabývajících se stínovým vzděláváním kritizující zejména malou pozornost věnovanou soukromému doučování. ${ }^{7}$ To si např́íklad Chan a Bray (2014) částečně vysvětlují tím, že její autoři působili či působí v Evropě, kde je fenomén soukromého doučování stále do značné míry skryt pozornosti akademické obce, politických představitelů či veřejnosti, na rozdíl třeba od asijských států. Situace se ale $\mathrm{v}$ poslední době začíná obracet, nebot' rostoucí popularita soukromého doučování začíná být stále zřetelnější zejména v některých evropských zemích, jak ukážeme v dalším textu. Soukromé doučování a především jeho institucionalizované formy lze ale vnímat jako jeden z projevů pronikání soukromého sektoru do veřejného školství (zejména v některých specifických národních kontextech), což s sebou přináší mnoho zřejmých, ale i skrytých implikací pro formální vzdělávací systém a spravedlnost ve vzdělávání.

Zajisté je možné identifikovat pozitiva soukromého doučování vnímaného jako investice do lidského kapitálu. Může žákovi pomoci dosáhnout lepších školních výsledků a zvládat požadavky kladené na něj ve škole. Z pohledu učitelů poskytujících doučování je to možnost získat dodatečné př́ijmy a žákům zajistit smysluplné naplnění volného času, rozšířit prostor pro sociální interakci s vrstevníky, pokud probíhá ve skupině (Bray, 2003, s. 13). Může sloužit také jako zdroj inspirace pro veřejné školy a jejich učitele, např. v otázkách inovací výuky a jejího zatraktivnění (Bray, 1999, s. 83).

Soukromé doučování je fenomén objevující se z různých př́íčin prakticky ve všech vzdělávacích systémech a díky neustále se rozšiřující poznatkové bázi získáváme i jasnější obraz jeho možných úskalí objevujících se v různých kontextech a s odlišnou mírou závažnosti. V první řadě je tento fenomén spojován s otázkami rovného př́ístupu ke vzdělávání, což je princip, který dominuje ve vzdělávacích politikách většiny vyspělých států, Evropskou unii nevyjímaje. ${ }^{8}$ Soukromé doučování totiž zdaleka není dostupné všem žákům

7 Zpráva se pouze okrajově zmiňuje o tzv. cramming schools v Japonsku, na Taiwanu a v Koreji a individuálním doučování v UK a USA (Ball \& Youdell, 2008, s. 25).

8 Podpora spravedlnosti a sociální soudružnosti je jedním ze strategických cílů zakotvených v evropském dokumentu ET 2020 (Council conclusions of 12 May 2009 on a strategic framework for European cooperation in education and training, 2009). 
bez rozdílu a výše přímů rodiny má spolu s dalšími faktory ${ }^{9}$ významný vliv na participaci na soukromém doučování (Dang \& Rogers, 2008). Bohatší rodiny si mohou dovolit zakoupit větší množství hodin kvalitnějšího doučování, děti bohatších rodičů mohou oproti svým chudším vrstevníkům získat touto formou značnou výhodu třeba při př́pravě na přijímací zkoušky, které často rozhodují o vzdělávací dráze i budoucím profesním uplatnění. ${ }^{10}$ Má-li tedy veřejný vzdělávací systém poskytovat rovné př́ležitosti $\mathrm{k}$ učení všem bez rozdílu, chudým i bohatým, a vytvořit rovné př́ležitosti v soutěži o další vzdělávací místa, soukromé doučování financované ze soukromých zdrojů tedy ze své podstaty rovnost těchto príležitostí značně deformuje, jak argumentuje Heyneman (2011). V českém prostředí není autorovi známá žádná výzkumná studie, která by se na reprezentativním vzorku zabývala korelací mezi socioekonomickým statusem žáka a pravděpodobností využití soukromého doučování. Tuto souvislost však potvrdily některé výzkumy v sousedních zemích ${ }^{11}$ a s ohledem na specifika našeho kontextu lze předpokládat, že by se mohla potvrdit i v České republice.

V některých zemích je soukromé doučování spojeno s korupcí a rozmachem stínového trhu se vzděláváním. Biswal (1999) upozorňuje, že někteří učitelé mohou záměrně vynechávat některé části povinného kurikula, které pak

9 Např. nejvyšší dosažené vzdělání rodičů, velikost místa bydliště, míra selektivity přijímacích zkoušek do vyšších stupňủ vzdělávacího systému atd.

10 Např́́klad analýza odpovědí respondentů $(n=8713)$ mezinárodní srovnávací studie soukromého doučování v devíti postsocialistických zemích (Silova, Budiene, \& Bray, 2006, s. 91-92) ukazuje, že studenti vnímající bohatství své rodiny jako podprůměrné (vztaženo k národnímu průměru) využívají soukromého doučování méně často než studenti vnímající bohatství své rodiny nad národním průměrem. Až $70 \%$ respondentů se domnívá, že děti bohatých rodičů si mohou dovolit i lepší soukromé učitele (Silova et al., 2006, s. 92).

11 V Polsku se Długosz (2012) dotazoval žáků maturitních ročníků středních škol v jednom př́hraničním regionu v letech 2008 ( $\mathrm{n}=936), 2009$ ( $\mathrm{n}=1273)$ a $2011(\mathrm{n}=925)$. Zjistil, že mezi faktory nejsilněji korelované s využitím soukromého doučování patří vzdělání otce, množství movitých a nemovitých statků ve vlastnictví rodiny a subjektivně vnímaná finanční situace, dále pak i typ navštěvované školy.

Podobně v Německu prováděl Schneider (2004) sekundární analýzu dat z národního šetření Sozioëkonomischen Panel na vzorku 1266 sedmnáctiletých žáků. Zjistil, že žáci rodičů s vyššími př́ijmy (1. příjmový kvartil) využívají doučování více než dvakrát častěji než jejich vrstevníci z rodin s nižšími př́ímy (4. př́íjmový kvartil).

Na Slovensku Kubánová (2006) prováděla v rámci již zmíněného mezinárodního komparativního projektu (Silova, Budiene, \& Bray, 2006) dotazníkové šetření u studentů prvních ročníků vybraných vysokých škol $(n=926)$. Její závěry ukazují, že využití či nevyužití soukromého doučování souvisí se socioekonomickým statusem rodiny, tedy s povoláním rodičů, jejich vzděláním a také subjektivně vnímanou finanční situací rodiny. 
doučují soukromě za úplatu. Např́íklad v Kambodži mnoho studentů „povinně“ navštěvuje soukromé doučování před a po běžném vyučování. V podfinancovaném vzdělávacím systému totiž ve veřejných školách není pokryto celé národní kurikulum, což učitelům umožňuje nechat si od žáků za další doučování platit a získávat tak dodatečné př́imy. Často pak toto doučování probíhá ve školních budovách (Brehm \& Silova, 2014, s. 105).

Zdokumentovány jsou i možné negativní dopady na výuku ve škole. Pokud například v některých třídách určitá část žáků doučování využívá, mohou být učitelé konfrontováni s většími rozdíly ve školní úspěšnosti žáků. Někteří učitelé pomáhají méně úspěšným žákům, jiní ale mohou také považovat žáky využívající doučování za normu, což může vyvíjet tlak na ostatní žáky, kteří tak nečiní, a tak i stupňovat tlak na jejich rodiče, aby do soukromého doučování investovali (Bray, 1999). V českém prostředí by výše popsaná situace mohla potenciálně vznikat spíše na gymnáziích, kde se koncentrují žáci $\mathrm{s}$ lepším rodinným zázemím i vzdělanostními aspiracemi, tedy $\mathrm{v}$ prostředí s vyšší pravděpodobností využívání soukromého doučování žáky. Bohužel však relevantní výzkumná data, která by tuto domněnku potvrdila, v současné době chybí.

\section{Vládní přístupy $\mathrm{k}$ regulaci doučování}

Možné negativní dopady na vzdělávací systém, spravedlnost ve vzdělávání či korupce učitelů, na které jsme upozornili v předchozím textu v předchozí kapitole, mohou být př́činou i reakcí na politické i odborné úrovni. V některých případech motivovaly jednotlivé vlády, resp. tvůrce vzdělávací politiky zaujmout $\mathrm{k}$ danému problému postoj a reagovat opatřeními např. na legislativní úrovni. Vzdělávací politiky je pak možné klasifikovat podle toho, jaký postoj zaujímají ke sledovanému fenoménu, přičemž tyto př́istupy mohou v různých státech oscilovat mezi nevšímavostí až po úplný zákaz doučování. $V$ této stati vychází autor z typologie předního světového odborníka na fenomén stínového vzdělávání Marka Braye, ředitele Centra komparativních studií při Univerzitě Hongkong.

Jeho pojetí klasifikace vzdělávacích politik se v čase vyvíjelo. Ve své první přehledové publikaci na toto téma (1999) identifikoval šest typů př́istupů vlád k fenoménu soukromého doučování: (a) laissez-faire př́stup, charakteristický tím, že političtí představitelé stínový vzdělávací systém ignorují, aktivně se distancují od jakýchkoliv aktivit či intervencí s ním spojených; (b) moni- 
toring, charakteristický sběrem a vyhodnocováním dat o soukromém doučování, avšak bez podnikání dalších kroků; (c) regulace a kontrola, zahrnující např. regulaci výše poplatků za doučování, zákaz učitelům doučovat vlastní žáky atd.; (d) podpora, např. ve formě daňových úlev či dotací; (e) smíšený prístup, tedy podpora pouze některých a omezení jiných druhů doučování; (f) zákaz soukromého doučování, kdy bývá povolena pouze bezplatná pomoc neprospívajícím žákům.

Později (2003) tuto typologii zrevidoval a poněkud zredukoval: (a) ignorování fenoménu, (b) zákaz soukromého doučování, c) aktivní podpora soukromého doučování, (d) regulace a monitoring. ${ }^{12}$ Bray bohužel neposkytnul instrukce ani konkrétní „tvrdá" kritéria pro zařazení určité země do jednotlivých kategorií. Upřesnění a konkrétnější návod pro práci s touto typologií byl rozpracován až v mezinárodním srovnávacím výzkumu soukromého doučování v postsocialistických zemích (Silova, Budiene, \& Bray, 2006), z něhož je čerpáno i při identifikaci jednotlivých typů př́stupů ve vzdělávacích politikách evropských zemí v tomto textu. I v př́ípadě tohoto vymezení platí, že představuje víceméně ideální typy, které se v čisté podobě téměř nevyskytují, vždy půjde o jistou aproximaci založenou na tom, že některé země nemusí nutně uplatňovat všechna opatření. Nejprve bude pozornost věnována dvěma extrémům na stupnici podpora-zákaz.

\subsection{Podpora doučování}

Tato politika může mít své opodstatnění - vychází totiž z předpokladu, že soukromé doučování je do větší míry přizpůsobeno žákovi a tím ze své podstaty lépe uspokojuje jeho individuální učební potřeby. Tím přispívá k rozvoji lidských zdrojů i celé společnosti. Vlády mohou rovněž vidět soukromé doučování jako způsob zajištění vyšších příjmů učitelů a snížení nezaměstnanosti. Podpora soukromých subjektů poskytujících doučování může mít mnoho podob a je vždy otázkou, zda zůstává pouze na úrovni deklarací ve vládních dokumentech, nebo zda jsou realizována konkrétní opatření, např́klad organizovány kurzy pro tutory, zakládány webové portály pro setkávání poptávky s nabídkou nebo poskytovány daňové úlevy či dotace soukromým subjektům (Bray, 1999, s. 76).

12 Oproti původní verzi došlo ke sloučení př́istupu monitoring a regulace, pravděpodobně se tak stalo proto, že pouze málo států provádí pouze monitoring. Pokud jsou vynakládány finanční prostředky k monitoringu, zpravidla jsou sledovány i další cíle. 
V Evropě je známým příkladem země podporující soukromé doučování Francie. Dá se s jistou nadsázkou tvrdit, že podpora doučování zde vznikla jako vedlejší produkt politiky zaměstnanosti na přelomu 80. a 90. let. Ekonomická recese provázená vysokou nezaměstnaností motivovala vládu přijmout i méně obvyklá opatření. V zájmu vytvoření nových pracovních míst, snížení míry nelegální práce a tím i daňových úniků se vláda rozhodla fiskálně podporovat práci poskytovanou pro rodiny a domácnosti, které byly vnímány jako nevyužitý ekonomický potenciál pro tvorbu nových pracovních míst (Dumalin \& Rahou, 2008, s. 11). Zvýhodnění pro poskytovatele formou možnosti odečtu $50 \%$ základu daně z př́jmů z činností prováděných v domácnosti „zaměstnavatele“ (jako je kromě úklidu či hlídání dětí také doučování) je legislativně zakotveno v zákoníku práce (Code général des impôts, Article 199 sexdecies). Daňové zvýhodnění se týká pouze takového soukromého doučování, které probíhá v domácnosti doučovaného, popř. na jiném veřejném místě, a týká se př́mo předmětů vyučovaných ve škole. $V$ roce 1996 byla možnost daňového odpočtu umožněna nejen jednotlivcům nebo organizacím s povolením státu, ale byla garantována i soukromým institucím, které doučování zprostředkovávají. To byl podle Ollerové a Glasmana (2013) klíčový faktor, který ovlivnil masivní růst této části trhu - je to druhá polovina 90. let 20. století, kdy se rodí dnešní giganti „doučovacího průmyslu“ ve Francii. Trh ovládlo pět největších firem, ${ }^{13}$ pro které se stalo zprostředkovávání soukromého doučování výnosným byznysem. Díky vládní politice je pro ně tento trh velmi atraktivní a fiskální možnosti poskytované vládou se stávají běžnou součástí jejich marketingové strategie. ${ }^{14}$ Zajímavost soukromého doučování a ekonomický potenciál poptávky rodičů analyzují dokonce i soukromé poradenské firmy. Přestože byl trh soukromých poskytovatelů zasažen ekonomickou krizí a v minulosti byla zprostředkovatelským agenturám prokázána mnohá pochybení např́klad v otázce kvality lektorů, ${ }^{15}$ francouzská výzkumná agentura Xerfi (Desruelles, 2012) očekává další prudký růst sektoru soukromého doučování a upozorňuje na stále nevyužitý potenciál trhu, jehož zdrojem je „obava rodičů o budoucnost svých dětí, nedůvěra

13 Complétudes, Keepschool, Profadom, Cours Legendre a Acadomia, s jejímiž akciemi se dokonce obchoduje na burze.

14 Např́klad současná jednička na trhu Acadomia uvádí u svých „produktů“, které splňují podmínky výše uvedeného zákona, hodinovou sazbu již po slevě na dani (Acadomia, 2013).

15 Na některá z nich upozorňuje i dokumentární film „Le soutien scolaire- reussite ou echec!“ (Bendall \& Tourtre, 2009). 
ke vzdělávacímu systému, obava ze snížení sociálního statusu, nedostatek času rodičů..." (Desruelles, 2012, s. 1).

Kdo je tedy nejčastějším př́ijemcem této placené formy vzdělávání? Ve Francii se jak na základní, tak střední škole jedná převážně o žáky s dobrým rodinným zázemím. Část těchto žáků jak na základní, tak střední škole nedosahuje uspokojivých výsledků, jejich rodiče jsou často velmi vytížení a nemají čas se svým dětem věnovat. Existuje však podstatná část žáků středních škol (ze skupiny doučovaných asi $25 \%$ ), která je ve svém studiu úspěšná a jejíž primární motivací je dosahování nadprůměrných výsledkủ, resp. úspěch při přechodu do terciárního vzdělávání v prestižních oborech či univerzitách (CERC, 2008, s. 129). Vysokou konkurenci spojenou se školními výsledky považují Glasman a Besson (2004) za podstatný aspekt francouzského vzdělávacího systému. Vzdělání a vysokoškolský diplom je stále důležitější pro budoucí pracovní uplatnění, př́ímy a socioekonomický status. V těchto podmínkách pak mohou rodiny s vyšším socioekonomickým statusem s větší intenzitou investovat do vzdělávání svých dětí než rodiny z jiné sociální vrstvy (Glasman \& Besson, 2004, s. 58).

Na druhou stranu je nutné poznamenat, že francouzský vzdělávací systém poskytuje i bezplatné alternativy pro žáky ze znevýhodněného prostředí. Existuje rozsáhlá sít' programů doučování a individuální pomoci hrazená z veřejných prostředků, jejíž služby jsou cílené zejména na žáky s učebními potížemi. Jedná se o tzv. „individualizované programy pro školní úspěšnost“ (PPRE), „individualizovanou pomoc“ (aide personalisée), „specializovanou pomoc" (aide spécialisée) a další programy pomoci určené neprospívajícím žákům od prvního stupně po střední školu (Centre d'analyse stratégique, 2013). Fiskální úlevy snižují náklady na soukromé doučování, které ale zpravidla nevyužívají děti ze znevýhodněného sociálního prostředí. Je proto namístě otázka, kterou si kladou i autoři výzkumné zprávy CERC (2008), zda je opravdu potřeba „... mírnit nedostatky vzdělávacího systému opatřeními, která zvýhodňují již zvýhodněné..." (tamtéž, s. 3). V minulosti se sice objevily různé pokusy o omezení či dokonce úplné zrušení těchto fiskálních výhod, ${ }^{16}$ žádný však dosud nebyl úspěšný.

16 Za všechny můžeme zmínit např. návrh poslance Lionela Tardyho (2009), který měl tyto výhody odebrat zprostředkovatelským agenturám. 


\subsection{Zákaz soukromého doučování}

Opačným pólem výše popsaného př́ípadu může být pro českého čtenáře možná i relativně překvapivý zákaz poskytování soukromého doučování. Tuto cestu v minulosti volily některé vlády zejména ve východní Asii, např. Kambodža, Korea, Barma či Mauricius (Dang \& Rogers, 2008). Tento prŕístup se vyznačuje snahou vládních institucí potlačovat soukromé doučování, v extrémních př́padech jej zcela postavit mimo zákon. Vlády organizují veřejné kampaně proti doučování využívající sdělovacích prostředků, zároveň však mohou podporovat z veřejných zdrojů financované a pro neprospívající žáky bezplatné doučování, které bývá často poskytované dobrovolníky či neziskovými organizacemi. V neposlední řadě vymáhají dodržování zákazu a sankcionují ty jednotlivce či instituce, kteří jej porušují (Silova, Budiene, \& Bray, 2006, s. 103-108). Právě otázka vynutitelnosti takového zákazu je velmi problematická. Nejen že soukromé doučování je v mnohých kulturách tradiční a historicky zakořeněná praxe, takže existují tendence formální zákazy obcházet, ale navíc globalizace a IT technologie přinesly dramatickou změnu v možnostech poskytování doučování a umožnily fyzicky oddělit soukromého učitele od doučovaného žáka, čímž se tento zákaz stává ještě hůřre kontrolovatelný. ${ }^{17} \mathrm{~V}$ historii tento postoj uplatnilo několik států východní Asie, často citovaným př́kladem je Jižní Korea, kde se podle některých studií (např. Kim \& Lee, 2010) až tř́i čtvrtiny žáků primárních a sekundárních škol účastní stínového vzdělávání. M. Seth (2002) ve své historické analýze př́značně charakterizuje korejskou situaci jako „vzdělávací horečku“ (education fever). Vysoká poptávka po kvalitním vzdělání a z ní vyplývající silný konkurenční boj mezi žáky negativně ovlivňoval nejen peněženky jejich rodičů, ale i osobní životy žáků. Byli přetěžováni a trávili doučováním prakticky veškerý volný čas (Kim, 2007 citovaný podle Bray, 2009). Reakce vlády na tuto situaci byla poměrně radikální. Soukromé doučování bylo mezi lety 1980 až 1989 postaveno mimo zákon a za porušení zákazu hrozily i velmi tvrdé tresty včetně vězení (Hahn, Sung, \& Lee, 2013). Ukázalo se však, že ač uvedení takového zákazu v platnost je poměrně jednoduchá záležitost, neplatí totéž o jeho vymahatelnosti. Zákaz byl rodiči i doučujícími porušován a doučování probíhalo tajně. Navíc vyšší riziko ještě zvýšilo cenu za soukromé doučování (Bray, 2009).

17 Pronikáním IT technologií a proměnami soukromého doučovánív jejich důsledku se zabývají např́klad Ventura a Jang (2010). 
V Evropě by se země, ve které by bylo doučování zcela zakázáno, hledala obtížně. Tento poněkud extrémní prrístup se nepodařilo na základě rešerše literatury, legislativních norem ani vládních deklarací a dokumentů identifikovat v žádné evropské zemi, možná i s ohledem na fakt, že takový zákaz by zásadním způsobem omezoval právo na vzdělání v demokratické společnosti (Heyneman, 2011).

\subsection{Regulace a kontrola}

Dalším z možných přístupů k soukromému doučování může být jeho regulace a kontrola. Ta vychází ze znalosti kontextu, prríčin poptávky a nabídky a analýz dopadů soukromého doučování na spravedlnost ve vzdělávání. Vlády zpracovávají právní regulace doučování v souladu s širšími koncepcemi vzdělávací politiky. Často také zavádějí podporu žákủm, jejichž rodiny si nemohou dovolit drahé doučování, např. prostřednictvím doučování dobrovolníky nebo neziskovými organizacemi. Nastavují rovněž jasná pravidla, aby zamezily neetickému poskytování doučování, a mohou stanovovat standardy kvality poskytovaných služeb licencovaných institucí nebo jednotlivců poskytujících doučování. $V$ neposlední řadě se soustředí na změny formálního vzdělávacího systému tak, aby minimalizovaly potřebu soukromého doučování (Silova, Budiene, \& Bray, 2006, s. 103-108). Pokud je ponechána stranou všeobecně platná povinnost odvádět státu daně z příjmu a tedy nelegálnost poskytování doučování „načerno“, lze v Evropě najít několik příkladů zemí, které nějakým zpưsobem legislativně přímo upravují soukromé doučování, jeho poskytování nebo kvalifikaci doučujících, at’ už jako součást hlouběji propracované koncepce, nebo jako relativně izolovanou záležitost.

Právě otázka kvality poskytovatelů může být problematická, jak jsme již částečně upozornili v části týkající se Francie. Spektrum soukromých doučujících může být skutečně široké, od profesionálů v oboru přes učitele středních a základních škol až po studenty vysokých škol hledající přivýdělek. Motivace, odbornost, pedagogické schopnosti i finanční požadavky těchto skupin se přitom mohou značně lišit. Do jisté míry je regulována požadovaná kvalifikace poskytovatele doučování cizích jazyků na nám blízkém Slovensku. Podle zákona č. 455/1991 Zb. o živnostenském podnikání je výuka cizích jazyků vázanou živností a pro její vykonávání je kromě živnostenského oprávnění potřeba dokončené studium př́íslušných jazyků na vysoké škole, státní jazyková zkouška nebo prokázání alespoň desetiletého pobytu v zemi, kde je vyučovaný jazyk jazykem úředním. Doučování uměleckých předmětů je podmíněno vysokoškolským titulem z příslušného oboru či desetiletou 
praxí v oboru (př́loha č. 2 zákona 455/1991 Sb.). Výuku jiných předmětů ale zákon neupravuje. V praxi však podle Kubánové (2006) většina soukromých učitelů pracuje bez živnostenského oprávnění a své př́íjmy nezdaňuje.

Právní regulace učitele poskytujícího doučování je v Litvě poměrně dobře propracovaná. Zákon o vzdělávání v Litevské republice z roku 1991 (novelizován 2006) definuje soukromého učitele jako fyzickou osobu poskytující vzdělávání na individuální bázi v souladu s právními předpisy. Článek 50 tohoto zákona pak dále definuje jeho práva (poskytovat neformální vzdělávání založené na individuálních potřebách doučovaného, vybírat si vlastní metody a formy vyučování, poskytovat neformální konzultace), povinnosti (dodržovat zásady Etického kodexu učitelů, zajistit bezpečnost doučovaného, zajistit, aby místo doučování splňovalo hygienické normy) i určitá omezení (zakazuje mu doučovat vlastní žáky z předmětů, které má učitel ve škole na starosti). Budiene a Zabulionis (2006, s. 216) k tomu poznamenávají, že ačkoli je povinností poskytovat doučování na základě živnostenského oprávnění a odvádět ze svých př́ijmů daně v souladu s právem, činí tak reálně velmi malý počet učitelů. Jednak proto, že se snaží skrývat doučování jako do jisté míry neetické jednání, zejména v případě, že poskytují doučování vlastním žákům, a jednak také z ekonomických důvodů (nepřiznání daně z př́jmů). Dále také upozorňují, že se cena ročního živnostenského oprávnění pro soukromého učitele liší dle velikosti města, takže může být pro některé skupiny doučujících diskriminující. Možnosti státu kontrolovat a usvědčit učitele $\mathrm{z}$ daňových úniků prostřednictvím doučování „načerno“ jsou velmi omezené stejně jako kontrola dodržování norem a zásad Etického kodexu učitele.

V Německé spolkové republice také existuje právní rámec, který upravuje soukromé doučování a chování subjektů, které ho poskytují. Co se týče soukromých institucí poskytujících doučování, jsou v např. Hessensku považovány za součást soukromého sektoru a nepodléhají dohledu jako veřejné školy, podobně je tomu u institucí v Badensku-Würtembersku a Sasku (Dohmen et al., 2008, s. 58). V Braniborsku ale podléhá podle $§ 127$ Braniborského školského zákona (Brandenburgisches Schulgesetz) soukromé doučování více než čtyř žáků najednou ohlašovací povinnosti příslušnému školskému úřadu. ${ }^{18}$

18 „(1)Unterrichts-und Erziehungseinrichtungen, die keinen schulischen Charakter haben, unterliegen einer Anzeigepflicht bei dem zuständigen staatlichen Schulamt, wenn sie gewerblich betrieben werden und dabei auch regelmäßig Minderjährige betreffen. (2) Auf den gleichzeitigen Unterricht mit weniger als vier Personen finden die Bestimmungen des Absatzes 1 keine Anwendung." (Branderburgisches Schulgesetz, §127) 
Další omezení soukromého doučování se uplatňuje například v Sársku, a to již od roku 1975. Tam $\S 4$ odst. 2 Obecného služebního řádu pro učitele (Allgemeine Dienstordnung für Lehrer) výslovně stanovuje, že „... učitel nesmí poskytovat žádné placené doučování žákủm, které vyučuje ve škole“. ${ }^{19}$ Německo je tak představitelem federativní země, jejíž jednotlivé státy k problematice regulace soukromého doučování nezaujímají jednotný postup a mohou do jisté míry připomínat paralelu s EU a jejími členskými státy.

Přísnou regulaci soukromého doučování můžeme najít na Kypru. Stylianou et al. (2004) popisují všeobecně rozšířenou potřebu žáků využívat soukromého doučování doslova jako „mor“ (educational plague) a dále uvádějí, že „.... soukromé doučování je integrální součástí vzdělávacího systému do takové míry, že se stalo absolutní nezbytností, a je téměř jisté, že každý žák bude v některém momentě své školní docházky hledat doučování v jednom nebo i více předmětech“ (Stylianou et al., 2004, s. 335). To dokládají i na číslech ze svého dotazníkového šetření ( $\mathrm{n}=1120)$, podle kterého až $86 \%$ studentů středních škol využilo soukromé doučování. ${ }^{20} \mathrm{Na}$ Kypru existují tři typy institucí (Lamprianou \& Lamprianou, 2013) poskytující soukromé doučování. První jsou soukromé instituce mající licenci ministerstva školství (tzv. frontistira), které podléhají velmi silným regulacím a pravidelným kontrolám ministerstva. Zákony stanovují přesné podmínky pro zakládání, registraci a chod těchto institucí, požadavky na bezúhonnost či kvalifikaci lektorů, kurikulum a další. Tyto instituce se musí na žádost ministerstva podrobit inspekcím, které v př́padě nalezení nedostatků mohou instituci odebrat provozní licenci (Ministry of Education and Culture, 2012). Druhým typem jsou neregistrované instituce operující nelegálně. $V$ rámci této skupiny je možné identifikovat také učitele veřejných škol, kteří poskytují doučování tajně doma nebo na jiných neveřejných místech, přestože jim to zákon zakazuje. Konečně třetím typem jsou státní instituce poskytující doučování, které je dotováno $\mathrm{z}$ veřejných zdrojů. ${ }^{21}$ To autoři považují oficiální přiznání, že veřejný systém

19 „Der Lehrer darf Schülern, die er unterrichtet, keinen entgeltlichen Nachhilfeunterricht erteilen." (Allgemeine Dienstordnung Für Lehrer, § 4 odst. 2)

20 U doučovaných žáků byla mezi nejčastěji uváděnými důvody nedostatečná kvalita školní výuky $(47,8 \%)$, problémy se zvládnutím učiva $(41,2 \%)$ a př́prava na zkoušky na vysokou školu $(41,1 \%)$.

21 Těchto institucí je na Kypru celkem 41 a nabízejí své služby více než 17000 žáků ročně. Jejich posláním je pomoc žákủm z nízkopříjmových rodin, roční jazykové kurzy či příprava na státní zkoušky účastníky stojí 225-385 EUR ročně (Ministry of Education and Culture, 2011). 
vzdělávání selhal a upozorňují na jistý paradox, že „... stát opakovaně vyhlašoval válku doučování, ale zároveň sám poskytuje určitou verzi této služby, jen levněji“ (Lamprianou \& Lamprianou, 2013, s. 32-33). Dodržování zákonů a omezování nelegálně poskytovaného doučování se ale kyperské vládě nedaří efektivně vynucovat, jak to popisuje např. i novinový článek Cyprus Mail (2008), ve kterém sdružení institucí pro doučování SIFK kritizuje vládu a policii za přehlížení mnoha zjevných prohřešků, jakými jsou např́íklad billboardy propagující nelegální doučování visící mnohdy v těsné blízkosti policejních stanic. Je otázkou, do jaké míry přísné vládní regulace ztěžující provoz legálních institucí korelují s vysokou nabídkou nelegálních frontistir.

Monitorování a regulace sektoru soukromého doučování státem může mít i jiné opodstatnění vyplývající právě z propojenosti stínového vzdělávání $s$ veřejným vzdělávacím systémem. Pro aktéry vzdělávací politiky totiž může být jedním z indikátorů kvality veřejného školství poskytujícím zprostředkovaný odraz jeho př́padných nedostatků (Bray et al., 2011, s. 62). Následná analýza efektů soukromého doučování může pomoci hodnotit spravedlivost vzdělávacího systému, analýza příčin soukromého doučování informuje o kvalitě výstupů formálního vzdělávacího systému (Bregvadze, 2012, s. 81). Vlády, které se staví k soukromému doučování nevšímavě, se tak připravují o jeden z důležitých zdrojů informací o vlastním vzdělávacím systému, jak o tom bude řeč v následující kapitole.

\subsection{Nevšímavost}

Poslední zmiňovaný př́ístup je charakteristický tím, že političtí představitelé stínový vzdělávací systém ignorují a v této oblasti nijak neintervenují. Veselý (2013) poznamenává, že „nejednání" může vycházet ze skutečnosti, že se daný problém vůbec nedostane do agendy určité instituce, nebo může být důsledkem záměrného rozhodnutí určitým problémem se nezabývat (s. 289). V praxi se může jednat o vlády liberální, které se aktivně rozhodnou do této oblasti nezasahovat a ponechat doučování tržním silám (tradičně je uváděna jako př́klad Kanada a Velká Británie), nebo vlády, které by rády v této otázce jednaly, nicméně pro zásahy jim chybí zdroje (lidské, finanční) či dostatečně silné instituce. Jako př́klad mimoevropských zemí bývají uváděny Nigérie či Srí Lanka (Silova, Budiene, \& Bray, 2006; Dang \& Rogers, 2008). Přestože je ignorování soukromého doučování ze strany tvůrců vzdělávací politiky poměrně častý přístup, nemusí být vždy nejvhodnější, zejména ve vzdělávacích systémech s nízkou mírou akontability, nízkými platy učitelů veřejných škol 
či všeobecnou tolerancí ke korupčnímu jednání. Učitelé mohou sami vytvářet poptávku po doučování tím, že záměrně vynechají části kurikula, jehož zvládnutí je potřebné například ke složení postupových zkoušek do dalšího ročníku. Toho poté mohou využívat při nabízení vlastního doučování svým žákům mimo školní vyučování. Rodiče mohou být postaveni před otázku, zda zaplatit za extra doučování, či riskovat, že jejich dítě bude nuceno opakovat ročník (např. Bray \& Kwok, 2003; Bray, 1999).

Jako příklad evropské země spadající do této kategorie je možné uvést Chorvatsko. Jak zmiňují autoři Ristic Dedić, Jokić a Jurko (2006),

... chorvatské Ministerstvo vědy, vzdělávání a sportu nikdy veřejně nedefinovalo svůj postoj vǔči soukromému doučování ani jej nijak neregulovalo. Další vzdělávání nabízené soukromými institucemi ... je vnímáno jako jakékoliv jiné podnikání a není pod dohledem ministerstva. (s. 169)

Závěry jejich výzkumu potvrdily do té doby pouze tušenou všeobecnou rozšířenost doučování mezi žáky středních škol (až 54,5 \% žáků veřejných středních škol využilo doučování alespoň v jednom předmětu). Autoři tuto rozšířenost doučování přisuzují třem hlavním faktorům. Prvním je př́liš náročné školní kurikulum spojené $\mathrm{s}$ vysokým průměrným počtem studentů ve třídě, které snižuje možnosti individuálního př́ístupu učitele. Druhým je vzrůstající konkurence v boji o přijetí do vysokoškolského vzdělávání spojená s nekompatibilitou školního kurikula a požadavků přijímacích zkoušek na mnohé univerzity. Konečně třetí důvod připisují klesající prestiži profese učitele spojené se snižující se kupní silou učitelů. Na základě navazujícího kvalitativního výzkumu (Jokić, Soldo, \& Ristic Dedić, 2013), kterého se účastnili různí aktéři doučování (rodiče, žáci, učitelé, představitelé vlády), pak poukázali na rozdíly ve využívání soukromého doučování žáky s různým socioekonomickým statusem. Zatímco žáci z „lepších“ rodin využívají doučování spíše pravidelně a plánovitě, po delší časové úseky, žáci z rodin s nízkým socioekonomickým statusem využívají méně kvalifikovaných, a tedy i levnějších doučujících spíše nárazově. Autoři rovněž upozorňují na pasivní roli státu a nízké ambice reagovat ve prospěch větší spravedlnosti formálního vzdělávacího systému. 


\section{Diskuze}

V předloženém textu byl podán přehled různých př́ístupů tvůrců vzdělávací politiky v Evropě k sektoru soukromého doučování a jeho př́padné regulaci. Vybrané země ilustrují širokou škálu možností, které mají tvưrci vzdělávací politiky ve vztahu k doučování $k$ dispozici. Na základě vybraných závěrů empirických šetření bylo rovněž poukázáno na možné důsledky existence soukromého doučování, především s ohledem na spravedlnost ve vzdělávání.

Je tedy úkolem vlády či stakeholderů ve vzdělávání zabývat se nejen formálním vzdělávacím systémem, ale i systémem „stínovým“? Proti hovoří hlasy liberálů a zastánců volného trhu, podle kterých by neměl stát zasahovat do soukromých záležitostí a ponechat na osobním zvážení a svobodném a dobrovolném rozhodnutí, zda zájemce za doučování zaplatí a kolik. Protiargumenty druhé strany pak vycházejí zejména z empiricky prokázaných negativních dopadů přebujelého sektoru soukromého doučování. Zastánci této strany (často z řad akademiků dlouhodobě se tématem zabývajících) se domnívají, že pokud bude stínové vzdělávání přenecháno pouze tržním silám, jeho intenzita vzroste, což povede k udržování a prohlubování společenských nerovností (Bray et al., 2011). Deklarují-li tedy tvůrci české vzdělávací politiky jako jeden z principů vzdělávacího systému jeho spravedlnost (MŠMT, 2001, s. 17), nelze dle názoru autora existenci stínového vzdělávacího systému přehlížet, at’ záměrně, či nezáměrně.

Zatím však byla v České republice tomuto fenoménu věnována jen malá pozornost nejen ze strany tvůrců vzdělávací politiky, ale i výzkumných pracovníků. ${ }^{22}$ Je proto nejdřive potřeba porozumět stínovému vzdělávání a jeho lokálním specifikům, analyzovat jeho interakci s formálním vzdělávacím systémem, identifikovat př́činy jeho existence i typ žáků, kteří je využívají. Jinými slovy monitorovat situaci, sbírat data a vyhodnocovat je, jak to doporučují i světoví odborníci na tuto problematiku (např. Bray, 1999; Heyneman, 2011). Monitoring by mohl být realizován v rámci již existujících institucí, př́padně na evropské úrovni tak, aby členským státům poskytoval srovnatelná data. Určité, možná ekonomičtějši ř řešení by také představovala modifi-

22 Kromě několika málo závěrečných absolventských prací (Höschlová, 2012; Korpasová, 2009) není autorovi znám komplexnější empirický výzkum, který by zkoumal rozšśŕenost, formy nebo obsah doučování, příčiny nebo motivaci doučujících a doučovaných, cenovou dostupnost či kvalitu těchto služeb. 
kace či rozšíření dotazníků k výzkumu čtenářské gramotnosti PISA $^{23}$ o další otázky, které by blíže specifikovaly povahu doučování, jež respondent využívá či platí, čímž by se získala reprezentativní data o míře využívání soukromého doučování alespoň ve věkové skupině patnáctiletých.

Následným logickým krokem by byla diskuze, zda jej nějakým způsobem regulovat. Podobně jako v jiných oblastech může pedagogický výzkum spíše doporučovat a politickým reprezentantům odborně radit. Nicméně nejen př́klad Kypru a Litvy ukazuje, jak komplikovaná může být pro státní instituce kontrola dodržování nastavených regulací. $\mathrm{V}$ př́ípadě individuálního doučování je povaha této činnosti spolu s přirozenou tendencí poskytovatele i př́ijemce doučování chovat se ekonomicky (nepřiznání daně je finančně výhodné pro obě strany) předpokladem pro úniky do šedé zóny. Probíháli doučování na soukromém místě (např. v domácnosti doučovaného), je velmi obtížné, ne-li nemožné, pro státní aparát kontrolovat, zda probíhá v souladu se všemi předpisy. Měla-li by tedy být jakákoliv forma regulace uvedena do praxe, měli by regulátoři dobře zvážit, zda náklady vynaložené na její kontrolu budou úměrné jejím výnosům a zda celkový efekt bude pozitivní. Rovněž zákaz doučování by byl velmi problematický. Poučeni ze zkušenosti jiných států, je možné předpokládat, že taková politika není řešením prríčin, ale pouze symptomů, které mohou poukazovat na slabá místa veřejného školství.

Téma se dostalo také do evropské agendy, při formulaci doporučení pro český kontext tak mohou být jedním z východisek i doporučení expertů NESSE. Ve své analýze vypracované na žádost orgánů Evropské unie uvádějí několik univerzálních doporučení evropských vládám: (a) požadovat po jednotlivci nebo společnosti poskytující doučování oficiální registraci, (b) u registrovaných subjektů požadovat dodržování určitých standardů (např. požadavků na bezpečnost nebo bezúhonnost učitelů), (c) zákaz doučování vlastních žáků pro učitele ve školách (Bray et al., 2011). Poslední bod by byl pro české

${ }^{23}$ Jak známo, součástí tohoto mezinárodního výzkumu je i kontextuální žákovský dotazník. Ten například v roce 2009 zjištoval, jaké druhy mimoškolní výuky žák navštěvuje (otázka 31) a kolik hodin týdně jim věnuje (otázka 32) (OECD, 2009). Někteří autoři (např. Southgate, 2009) na základě těchto odpovědí odvozují míru rozšíření stínového vzdělávání a využívají tato data k sekundárním analýzám. Jak ale správně poukazuje Bray (2010), formulace otázky nedokáže rozlišit mezi placeným a neplaceným doučováním a případnými finančními náklady, nezkoumá ani motivaci žákủ k účasti na těchto aktivitách či blíže nespecifikuje jejich poskytovatele. Tyto informace jsou ale pro diagnostiku stínového vzdělávacího systému a zhodnocení možných implikací pro formální vzdělávací systém považovány za kruciální. 
školství zvlášt' relevantní v případě, že by závěry případného výzkumu rozšíření soukromého doučování v českém kontextu ukázaly na vysoké zastoupení učitelů středních či základních škol jako poskytovatelů soukromého doučování, nadto třeba vlastním žákům. Pak by bylo vhodné provést hloubkovou analýzu motivace těchto učitelů a vyhodnotit př́padná etická rizika z této praxe plynoucí. V některých zahraničních zemích je tato praxe symptomem kombinace špatně fungujícího vzdělávacího systému a nízkých platů učitelů ve veřejných školách, které mohou být motivem pro vyhledávání dodatečných př́ijmů z poskytování soukromého doučování vlastním žákủm (např. viz Popa \& Acedo, 2006). Na relativně nízké platy českých učitelů a podfinancování českého vzdělávacího systému se přitom upozorňuje dlouhodobě.

Vrátíme-li se k úvodní metafoře, lze konstatovat, že i u nás funguje paralelně s formálním vzdělávacím systémem ten stínový. Do jaké míry se oba systémy v ČR navzájem ovlivňují? Jaké jsou formy, obsahy či rozsah tohoto stínového vzdělávacího systému? Jací žáci soukromé doučování využívají a za jakým účelem? Jedním z aktuálních témat odborné diskuze je polemika nad požadavky na kvalifikaci učitelů základních a středních škol. Neměli bychom si stejnou otázku klást i v př́ípadě soukromých doučujících a jejich kvality, odbornosti či jejich pedagogických schopností a dovedností? Přestože jsou u nás k existenci i fungování soukromého doučování historicky i kulturnějiné předpoklady než v Koreji nebo jiných zemích s velmi rozvinutým systémem stínového vzdělávání, je toto téma svými potenciálními důsledky natolik závažné, že by mělo být akcentováno v národních i evropských odborných diskuzích s tvůrci vzdělávací politiky či výzkumníky. Zodpovědět tyto závažné otázky a navrhnout adekvátní politickou odezvu bude ale nejprve vyžadovat relevantní výzkumná data.

\section{Literatura}

Acadomia. (2013). Soutien scolaire hebdomadaire au lycée. Acadomia.fr [online]. Dostupné z www.acadomia.fr/niveau/lycee/cours-particuliers/soutien-hebdomadaire.html

Ball, S. J., \& Youdell, D. (2008). Hidden privatisation in public education. Brussels: Education International.

Belot, L. (2011). Parents stressés cherchent soutien scolaire. Le Monde [online]. Dostupné z http:// www.lemonde.fr/ecole-primaire-et-secondaire/article/2011/12/23/parents-stressescherchent-soutien-scolaire_1621634_1473688.html

Bendall, L., \& Tourtre, L. (2009). Le soutien scolaire, réussite ou échec? France 2 - Envoyé Special. Dostupné z http://www.cours-de-maths-78.fr/blog/2009/01/envoye-special-france-2reportage-sur-le-soutien-scolaire- $\%$ E2 $\% 80 \% 9$ Cle-soutien-scolaire-reussite-ou-echec\%E2\%80\%9D/. 
Biswal, B. (1999). Private tutoring and public corruption: A cost-effective education system for developing countries. The Developing Economies, 37(2), 222-240.

Bray, M. (1999). The shadow education system: Private tutoring and its implications for planners. Paris: International Institute for Educational Planning.

Bray, M. (2003). Adverse effects of private supplementary tutoring: Dimensions, implications and government responses. Paris: International Institute for Educational Planning.

Bray, M. (2009). Confronting the shadow education system: What government policies for what private tutoring? Paris: United Nations Educational, Scientific and Cultural Organization.

Bray, M. (2010). Researching shadow education: Methodological challenges and directions. Asia Pacific Education Review, 11(1), 3-13.

Bray, M. et al. (2011). The challenge of shadow education: Private tutoring and its implications for policy makers in the European Union. Brusel: NESSE.

Bray, M., \& Kwok, P. (2003). Demand for private supplementary tutoring: Conceptual considerations, and socio-economic patterns in Hong Kong. Economics of Education Review, 22(6), 611-620.

Bregvadze, D. (2012). Analyzing the shadows: Private tutoring as a descriptor of the education system in Georgia. International Education Studies, 5(6), 80-89.

Brehm, W. C., \& Silova, I. (2014). Hidden privatization of public education in Cambodia: Equity implications of private tutoring. Journal for Educational Research Online, 6(1), 94-116.

Budiene, V., \& Zabulionis, A. (2006). Lithuania. In I. Silova, V. Budiene, \& M. Bray (Eds.), Education in a hidden marketplace: Monitoring of private tutoring (s. 211-235). New York: Open Society Institute.

Burch, P. (2009). Hidden markets: The new education privatization. New York: Routledge.

Centre d'analyse stratégique. (2013). Quelle organisation pour le soutien scolaire?: la note d'analyse $n$. 315. Paris: Centre d'analyse stratégiques.

CERC (2008). Les services á la personne: rapport $n$. 8. Paris: La documentation française.

European Union (2009). Council Conclusions of 12 May 2009 on a strategic framework for European cooperation in education and training (ET 2020). Official Journal of the European Union, C 119, 28 May 2009. Dostupné z http://eur-lex.europa.eu/LexUriServ/LexUriServ. do?uri=0J:C:2009:119:0002:0010:CS:PDF

Cyprus Mail. $(2008,30.12$.). Private tutors urge crackdown on illegal lessons. Cyprus Mail [online]. Dostupné z http://www.cyprusedirectory.com/articleview.aspx?ID=6546

Dang, H., \& Rogers, F. H. (2008). The growing phenomenon of private tutoring: Does it deepen human capital, widen inequalities, or waste resources? The World Bank Research Observer, 23(2), 161-200.

Desruelles, V. (2012). Le marché du soutien scolaire á l'horizon du 2015. Quelles stratégies pour évangéliser un marché à fort potentiel, mais encore sous-exploité? Paris: Xerfi. Dostupné z http://www.xerfi.com/etudes/2SME36.pdf

Dohmen, D., Erbes, A., Fuchs, K., \& Günzel, J. (2008). Was wissen wir über Nachhilfe? - Sachstand und Auswertung der Forschungsliteratur zu Angebot, Nachfrage und Wirkungen. Berlin: Forschungsinstitut für Bildungs-und Sozialökonomie.

Długosz, P. (2012). Korepetycje maturzystów pogranicza w latach 2008-2011. Kultura i edukacja, 88(2), 88-106.

Dumalin, F., \& Rahou, N. (Eds.). (2008). Services à la personne: Evolutions, organisation et conditions de travail. Lyon: Agence Nationale pour l'Amélioration des Conditions de Travail. 
Franghi, C. (2011). Dans le monde, le soutien scolaire prospère là où l'école faillit. Le nouvel observateur [online]. Dostupné z http://www.rue89.com/2011/11/17/dans-le-monde-lesoutien-scolaire-prospere-la-ou-lecole-faillit-225783

Glasman, D., \& Besson, L. (2004). Le travail des élèves pour l'école en dehors de l'école. Paris: Haut conseil de l'évaluation de l'école.

Hahn, S., Sung, T., \& Lee, K. (2013). Private tutoring and educational inequality. Př́spěvek prezentovaný na 72th výroční konferenci na Yokohama National University, Yokohama. Dostupné z http://www.jsie.jp/Annual_Conferences/72th_Yokohoma_n_Univ/pdf/5_2\% 20fp.pdf

Heyneman, S. P. (2011). Private tutoring and social cohesion. Peabody Journal of Education, 86(2), 183-188.

Höschlová, M. (2012). Rozsah a příčiny doučování na prvním stupni ZŠ. (Diplomová práce). Dostupné z https://is.cuni.cz/webapps/zzp/detail/95095/?lang=cs.

Chan, C., \& Bray, M. (2014). Marketized private tutoring as a supplement to regular schooling: Liberal studies and the shadow sector in Hong Kong secondary education. Journal of Curriculum Studies, 46(3), 361-388.

Jokić, B., Soldo, A., \& Ristic Dedić, Z. (2013). Private tutoring and social equity in Croatia and Bosnia \& Herzegovina: A qualitative comparative study. In M. Bray, et al., Private tutoring across the Mediterranean (s. 11-27). Rotterdam: Sense Publishers.

Kim, S., \& Lee, J. H. (2010). Private tutoring and demand for education in South Korea. Economic Development \& Cultural Change, 58(2), 259-296.

Koleticiek, A. (2005). Bez korepetycji ani rusz. Dziennik Polski [online]. Dostupné z http://www. dziennikpolski24.pl/artykul/1740136,bez-korepetycji-ani-rusz,id,t.html

Korpasová, P. (2009). Private supplementary tutoring in English language. (Bakalářská práce). Dostupné z http://is.muni.cz/th/215712/ff_b/

Kubánová, M. (2006). Slovakia. In I. Silova, V. Budiene, \& M. Bray (Eds.), Education in a hidden marketplace: Monitoring of private tutoring (s. 279-303). New York: Open Society Institute.

Lamprianou, I., \& Lamprianou, T. A. (2013). Charting private tutoring in Cyprus: A sociodemographic perspective. In M. Bray, et al., Private tutoring across the Mediterranean (s. 29-56). Rotterdam: Sense Publishers.

Loveys, K. (2011). Rise of the tutor as parents lose faith in classroom teaching. MailOnline [online]. Dostupné z http://www.dailymail.co.uk/news/article-2033770/Rise-tutorparents-lose-faith-classroom-teaching.html\#ixzz2LAaOSxnr

Ministerstvo školství, mládeže a tělovýchovy (MŠMT). (2001). Národní program rozvoje vzdělávání v České republice: Bílá kniha. Praha: Tauris. Dostupné z http://aplikace.msmt. $\mathrm{cz} / \mathrm{pdf} /$ bilakniha.pdf

Ministry of Education and Culture (2011). State institutes for further education. Dostupné $\mathrm{z}$ http://www.moec.gov.cy/kie/pdf/state_institutes_further_education_en.pdf

Oller, A. C., \& Glasman, D. (2013). Education as a market in France: Forms and stakes of private tutoring. In M. Bray, et al., Private tutoring across the Mediterranean (s. 77-91). Rotterdam: Sense Publishers.

Organizace pro Ekonomickou Spolupráci a Rozvoj (OECD). (2009). Žákovský dotazník studie PISA 2009. Praha: Ústav pro informace ve vzdělávání. Dostupné z http://www.csicr. cz/getattachment/cz/O-nas/Mezinarodni-setreni-archiv/PISA/PISA-2009/zakovskydotaznik.pdf 
Popa, S., \& Acedo, C. (2006). Redefining professionalism: Romanian secondary education teachers and the private tutoring system. International Journal of Educational Development, 26(1), 98-110.

Ristic Dedić, Z., Jokić, B., \& Jurko, L. (2006). Croatia. In I. Silova, V. Budiene, \& M. Bray (Eds.), Education in a hidden marketplace: Monitoring of private tutoring (s. 169-189). New York: Open Society Institute.

Seth, M. J. (2002). Education fever: Society, politics, and the pursuit of schooling in South Korea. Honolulu: University of Hawaii Press.

Schneider, T. (2004). Nachhilfe als Strategie zur Verwirklichung von Bildungszielen. Eine empirische Untersuchung mit Daten des Sozioökonomischen Panels (SOEP) (No. 447). DIWDiskussionspapiere.

Silova, I., Budiene, B., \& Bray, M., (Eds.). (2006). Education in a hidden marketplace: Monitoring of private tutoring. Budapest: Education Support Program (ESP) of the Open Society Institute.

Southgate, D. E. (2009). Determinants of shadow education: A cross-national analysis (Disertační práce). Dostupné z http://etd.ohiolink.edu/send-pdf.cgi/Southgate\%20Darby\%20E.pdf? osu1259703574

Stylianou, V., Savva, A., Vraka, M., \& Serghiou, A. (2004). Information and communication technology: First-aid to the private tutoring problem? In Proceedings of the Sixth International conference on Computer-Based Learning in Science (s. 334-343). Nicosia: University of Cyprus.

Ventura, A., \& Jang, S. (2010). Private tutoring through the internet: Globalization and offshoring. Asia Pacific Education Review, 11(1), 59-68.

Veselý, A. (2013). Vzdělávací politika: rozdílná vymezení, předpoklady a implikace. Pedagogická orientace, 23(3), 279-297.

\section{Citované zákony a právní akty}

Code général des impôts (CGI) 2014. Article 199 sexdecies. Dostupný z http://legifrance. gouv.fr/affichCodeArticle.do;jsessionid=516E95E3832A71F0A38BE9E342B8E955. tpdjo14v_1?idArticle=LEGIARTI000028447562\&cidTexte=LEGITEXT000006069577\& categorieLien $=$ id\&dateTexte $=20140310$

Tardy, L. (2009) AMENDEMENT Nº II - 127 au Loi de Finances pour 2010 - (n 1946). Dostupný z http://www.assemblee-nationale.fr/13/pdf/amendements/1946/1946C0127.pdf

Ministry of Education and Culture (2012). The private Schools and Frontistira Laws of 1971 to 2012. Dostupné z http://www.moec.gov.cy/idiotiki_ekpaideusi/nomothesia/nomos_ idiotika_scholeia_1971_2012.pdf

Law on the Amendment of the Law on education 25 June 1991 No. I-1489, Vilnius (As new version by 17 June 2003 No. IX-1630) (As last amended on 13 June 2006 û No X-689). Dostupný z http://planipolis.iiep.unesco.org/upload/Lithuania/Lithuania_Amendment_ Law_on_Education_2006-2003.pdf

Gesetz über die Schulen im Land Brandenburg (Brandenburgisches Schulgesetz- BbgSchulG) (2011). Dostupný z http://www.bravors.brandenburg.de/sixcms/detail.php?gsid=land_ bb_bravors_01.c.47195.de

Allgemeine Dienstordnung für Lehrer (ADOL) (1975). Dostupný z http://www.vorschriften. saarland.de/verwaltungsvorschriften/vorschriften/dienstordnung_fuer_lehrer.pdf

Zákon č. 455/1991 Zb. o živnostenskom podnikaní ve znění pozdějších předpisů. Zbierka zákonov č. 87/1991. Dostupný z www.vyvlastnenie.sk/predpisy/zivnostensky-zakon 


\title{
Autor
}

Mgr. Bc. Vít Štastný, Univerzita Karlova, Pedagogická fakulta, Ústav výzkumu a rozvoje vzdělávání, Myslíkova 7, 11000 Praha 1, e-mail: vit.stastny@pedf.cuni.cz

\section{Private supplementary tutoring and education policies in Europe}

\begin{abstract}
The objective of this paper is to identify and classify European countries according to Bray's typology of education policies towards private supplementary tutoring $(1999,2009)$ and, based on literature review, show implemented regulations and their impact. In the first part the author defines private supplementary tutoring and describes its possible implications for formal education system and its equity. In the second part Bray's typology of education policies towards private tutoring and its chronological evolution is introduced. Policy types are demonstrated on specific examples of European countries. In the third part the author discusses the current situation in the Czech Republic. In Europe it is possible to identify not only the countries which support private tutoring (France), but also countries which regulate it in some way (Lithuania, Germany, Slovakia) or also those ignoring it (Croatia). Mentioned examples show the variability of shadow education system in various contexts and up to now reactions of educational stakeholders. Ignoring of this phenomenon in the Czech Republic contrasts with the recommendations of recognized experts. At the same time we lack relevant research findings that would support political decisions.
\end{abstract}

Keywords: private supplementary tutoring, shadow education, equity in education, European Union, regulation, legislation

Kostelecká, Y., Kostelecký, T., Kohnová, J., Tomášová, M., Pokorná, K., Vojtíšková, K., \& Šimon, M. (2013). Žáci-cizinci v základních školách. Fakta, analýzy, diagnostika. Praha: Univerzita Karlova v Praze, Pedagogická fakulta.

Schopnost ovládat jazyk majoritní společnosti je jednou z klíčových determinant úspěchu jedince a významnou podmínkou jeho bezproblémové integrace do dané společnosti. Žáci českých základních škol, jejichž komunikační dovednosti jsou v českém jazyce z jakéhokoliv důvodu omezené, mívají na základních školách problémy, a to nejen v hodinách českého jazyka, ale druhotně i v mnoha dalších předmětech, což může následně významně snížit jejich šance na dosažení dobrého vzdělání. Nedostatečná znalost češtiny neovlivňuje negativně pouze školní výsledky, ale může se promítat také do sociální oblasti. Cílem knihy je alespoň částečně zaplnit mezeru v oblasti výzkumu integrace dětí, jejichž rodným jazykem není čeština, do českých škol. 